\title{
The transition to farming and the ceramic trajectories in Western Eurasia: from ceramic figurines to vessels
}

\author{
Mihael Budja \\ Department of Archaeology, Faculty of Arts, University of Ljubljana, SI \\ miha.budja@ff.uni-lj.si
}

\begin{abstract}
In Eurasia the invention of ceramic technology and production of fired-clay vessels has not necessarily been related to the dynamics of the transition to farming. The invention of ceramic technology in Europe was associated with female and animal figurine making in Gravettian technocomplex. The fired-clay vessels occurred first in hunter-gatherer contexts in Eastern Eurasia a millennia before the agriculture. The adoption of pottery making in Levant seems to correlate with the collapse of the 'ritual economy', social decentralization and community fragmentation in the Levantine Pre-Pottery Neolithic. In South-eastern Europe the adoption of pottery making was closely associated with social, symbolic and ritual hunter-gatherers' practices.
\end{abstract}

IZVLEČEK - Začetki in razvoj keramične tehnologije ter lončarstvo v Evraziji niso vezani na pojav kmetovanja. V Evropi so najstarejši keramični artefakti - figurice v obliki ženskih in živalskih teles dokumentirati v Gravettianu. Najstarejše lončene posode se pojavijo v vzhodni Aziji, tisočletja pred kmetovanjem. V Levanti pojav lončarstva sovpada s kolapsom 'ritualne ekonomije' in družbeno decentralizacijo na koncu predkeramičnega neolitika. V jugovzhodni Evropi so začetki lončarstva povezani z različnimi socialnimi, simbolnimi in ritualnimi praksami lovcev in nabiralcev.

KEY WORDS - ceramic technology invention; demic diffusion; ritual economy; transition to farming

\section{Introduction}

The appearance of ceramic technology and production of fired-clay vessels has an extended history that has not necessarily been related to the dynamics of the transition to farming. It is increasing clear that diverse forms of ceramic technology had been 'inhabited' into the agency of Eurasian hunter-gatherers long before the emergence of sedentary social structures appeared. The invention of ceramic technology in Europe was associated with female and animal figurine making in Gravettian techno-complex, dated to about $26000 \mathrm{BP}$. The introduction of fired-clay vessels occurred first in hunter-gatherer contexts in Eastern Eurasia, where it was associated with small-scale sedentary or semi-sedentary commu- nities millennia before the advent of agriculture. The adoption of pottery making in Levant seems to have been caught up in processes of social decentralization and community fragmentation, which were part of the collapse of the 'ritual economy' in the Levantine Pre-Pottery Neolithic. In the South-eastern Europe the adoption of pottery making seems to have been incorporated within the hunter-gatherers' social, domestic and mortuary structures. It was the agency of hunter gatherers which initiated and made possible, both the later structural transformations in the economy, but also the almost simultaneous dispersal of a new form of ceramic materiality into the region. 


\section{Neolithic demic diffusion and the ceramic figurine paradox}

Jacques Cauvin (1978.134; 2000.22-29, 204-205, 207-208) has postulated that Levantine ceramic female figurines were markers of the new 'expansionist' religion, which became a powerful social force and facilitated at an ideological level the transition to an agricultural way of life. In identifying what he understood was clear evidence for an inter-linked economic and religious transformation he believed that he had also discovered the reason why hunter gatherer people in villages outside the Levant did not develop subsistence production for themselves. He suggested that their failure to move over to the 'humanisation' of art and related new divinities could also have prevented them from moving over to a new type of economic practice. According to this interpretative scenario Europe thus could not have become Neolithicised until the 'wave of advance' and ceramic female figurines had reached the Balkans.

It was suggested recently that the distribution of Neolithic ceramic female figurines appears to have links with human genetic evidence. As Roy King and Peter A. Underhill (2002.707-714) have hypothesised, these figures are perhaps 'the best genetic predictor' of Neolithic farmers' haplogrups and of the (re)population dynamics in Europe and Western Asia. It is due to the postulates that their geographic distribution correlates closely with the southeast-northwest cline of frequencies of $\mathrm{Y}$ chromosome markers and associated haplogroup Eu9 (J-M67* and J-M92 according to Semino et al. 2004.1030) in modern populations in Asia Minor and Europe, and, that all appear to originate in the same area of south-central Anatolia. The ceramic female figurines were hypothesised to appear at the same time as the emergence of cereal cultivation in the PPNA of the Levant. Moreover, they were believed to symbolise a series of gender and symbolic attributes that were carried forward with the spread of farming and went on to constitute part of the 'new materiality' that defined the key economic and ideological features of the Balkan Neolithic (Gimbuts 1989; Biehl 1996. 153-175; Marangou 1996. 176-2002; Chapman 2000; Bailey 2005; Hansen 2005. 199-200).

However, the introduction of ceramic female statuettes, ani- mal figurines and constructional ceramics were certainly not within the cultural domain of earlier Levantine hunter-gatherer societies, and nor they did not appear only on the 'eve of the appearance of an agricultural economy' as Cauvin (2000.25) suggested. The tradition of making figurines can be traced back to Central Europe, across the Russian Plain, into southern Siberia, and ultimately back to the Levant and Northern Africa. It is now clear that the clay figurine tradition was deeply embedded in pre-existing Eurasian hunter-gatherer social and symbolic contexts and that the dates of these figures begins as earlier as 26000 years BP (Verpoorte 2001; Budja 2004.59-81; 2005.53-72). For example, more than 16000 fragments of anthropomorphic figurines, zoomorphic statuettes, pellets, 'earplugs', flat fragments and constructional ceramic were recovered from the Central European Palaeolithic sites of Dolní Věstonice, Pavlov, Petřkovice, and Předmostí in Moravia. In the same region poorly preserved fragments of fired clay have also have also been recorded at KremsWachtberg, Moravany-Lopata, Jarošov, and hypothetically at Kašov and Cejkov (Soffer and Vandiver 1997.383-402; Verpoorte 2001) (Figs. 1 and 2), and while some may have been statuettes, their exact form remains unclear. Further to the East, on the Russian Plain, low-temperature-fired clay fragments were reported at Zaraisk and Kostenki Gravettian sites. At the latter, located on the banks of the River Don, more than four hundred fragments were found, contextually associated with marl and ivory Venus figures, and animal statuettes (Iakovleva 1999.125134; Soffer, Adovasio and Hyland 2000.511-537; Soffer et al. 2000.814). Finally, the most easterly anthropomorphic ceramic figurine was found at an open air site at Maininskaya (Maina), on the left bank of the Yenisei River in Siberia (Vasil'ev 1985.193196; Maina on-line).

All these early ceramic figurine assemblages can be assigned to the Pavlovian, a local variant of the Eastern Gravettian techno-complex, which dates back to

\begin{tabular}{|l|c|c|c|}
\hline Site & Anthropomorphic & Figurative & 'Ceramics' \\
\hline Dolní Věstonice I & 12 (note 1) & $>721$ & $>5,760$ \\
Dolní Věstonice II - north & - & $\geqslant 2(10 ?)$ & 431 \\
Dolní Věstonice II - west & - & 1 & 7 \\
Dolní Věstonice III & - & - & $1 ?$ \\
Pavlov I & 8 (note 1) & $? 100$ & $\sim 10,000$ \\
Pavlov II & - & $\geqslant 2$ & $\sim 135$ \\
Předmostí I & - & - & $>2$ \\
Jarošov II & - & 3 & $1 ?$ \\
Krems-Wachtberg (note 2) & - & & 3 \\
\hline
\end{tabular}

Fig. 1. Statistics of ceramic assemblages of Upper Palaeolithic Pavlovian sites in Central Europe (after Verpoorte 2001.Tab. 5.1). 


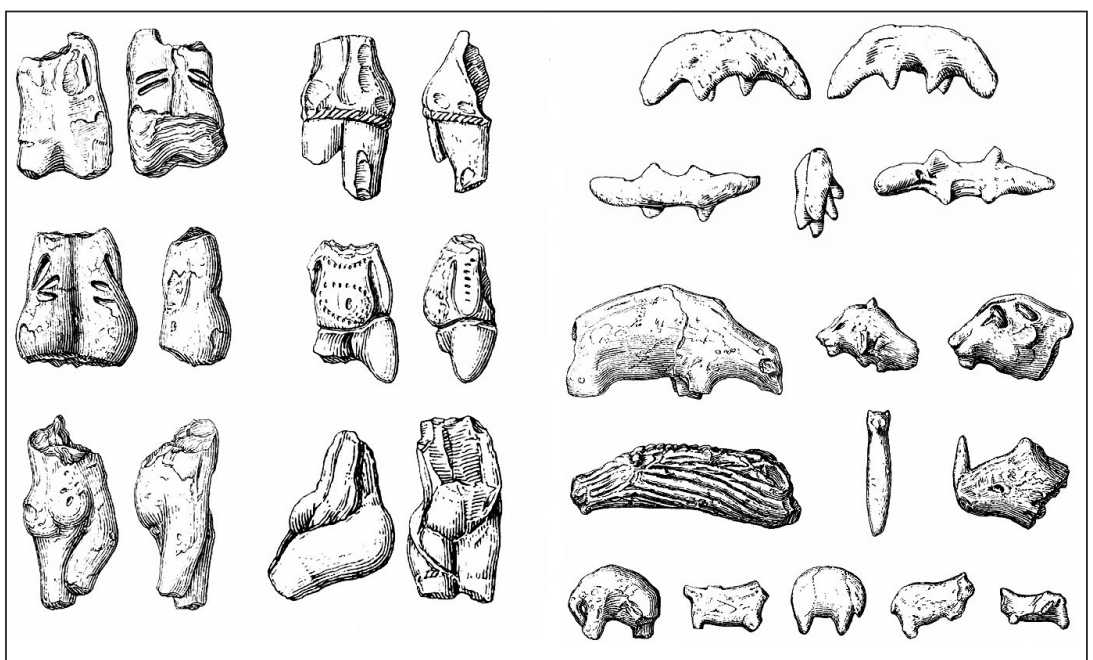

Fig. 2. Anthropomorphic and zoomorphic ceramic figurines from the Upper Palaeolithic Pavlovian sites Dolní Věstonice, Pavlov and Předmosti (from Verpoorte 2001.Figs. 3.6, 7, 8, 9, 46, 3.73, 8.1 and 54).
At the famous site of Dolní Věstonice there was an 'ovenlike hearth' located in the centre of the hut-like structure, where "two thousand pieces of 'ceramic', among which about one hundred and seventy-five with traces of modelling" were dispersed (Verpoorte 2001.56 and 128). In addition, other ceramic finds had been deposited in the vicinity of a single male burial, around a triple burial, and in the vicinity of a large hearth (Verpoorte 2001.95). The available statistics indicate that almost all the figurines and statuettes were deliberately fragmented, although many of the pellets and balls which form a large part of the ceramic inventory was found in an intact state.

Vandiver, Soffer, Klima and Svoboda (1989.10021008; Soffer et al. 1993.259-275; Sofer and Vandiver 1997.383-401) generated some very interesting insights into the material by attempting to reconstruct the ceramic production process by examining the technological skills involved. They discovered that the local loess was suitable for shaping the female figurines, animal statuettes and pellets. Figurines and statuettes had been made from several small pieces of clay joined together, with heads, legs, feet, ears and tails shaped separately and then attached to the bodies. Firing temperatures were low, between $500^{\circ}$ and $800^{\circ} \mathrm{C}$. However, the most important finding was widespread evidence that thermal shock, rather than breakage, had caused the fragmentation of the artefacts. This explosive reaction occurs when clay is subjected to sudden increases in temperature, for example during firing, and is especially violent when the clay is not fully dry. The researchers discovered that the figurines had been either dried or partially fired, but then subjected to a deliberate re-wetting after which they were cast into the fire where they would explode loudly sending fragments flying in many directions. Rather than being evidence for poor mastery of ceramic technology, they concluded that the communities were carefully exploiting and manipulating the inherent characteristics of the clay, with thermal shocking used deliberately for special visual and audible effect. This production for spectacular destruction was clearly of greater significance to the community than creation 
of an enduring and final artefact. In contrast, all ivory objects and stone figurines survive in fairly complete states. It is surprising that the entoptics, generally associated with the shaman's altered states of consciousness, were not attached to the new medium, the ceramics, although being broadly applied to ivory and bone imagery, and also stone figurines (Marshack 1991.24; Svoboda et al. 1996.167-168; Lewis-Williams 2002; 2004.107-111). The suggestions that the audio-visual effects of 'magic transubstantiation, the conversion of mud or dust into stone' (see Childe below), and figurine fragmentation simply replace them, and the visual and audible magic of the new medium, become accessible to the all members of community remain hypothetical.

We may postulate the ceramic female figurines are 'predictors', to paraphrase King and Underhill, of the Palaeolithic hunter-gatherers' as much as the Neolithic farmers' genetically determined haplogrups in Eurasia. It is unlikely that they represent the materialisation of the ideological conditio sine qua non for the successful transition to farming or the demic diffusion and the associated replacement of indigenous European population by which farmers expanded geographically, carrying with them their own culture (Budja 2005.53-72). We must note that the European genetic landscape was reshaped recently by the identification of subclades I1a, I1b*, I1b2, and I1c of I Y chromosomes. The haplogroup I is the only autochthonous haplogroup that is almost entirely restricted to the European continent where it shows frequency peaks in two areas, Scandinavia and Southeastern Europe (Semino et al. 2000.11551159; Rootsi et al. 2004.129-134; Barać et al. 2003. 535-542; Peričić et al. 2005.1964-1975; see also Peričic et al. and Rootsi in this volume). We must note that $I 1 b^{*}$ lineages expanded from the refuge in South-eastern Europe before the Neolithic at ca $11100 \pm 4800 \mathrm{BP}$.

\section{The invention of fired-clay vessels technology}

The invention of vessel technology has become archaeologically conceptualized with pottery making since Morgan (1878) hypothesised that in context of human social evolution 'lower barbarism' could be distinguished from 'upper savagery' by the presence of vessels, and, since Childe (1951) put forward the idea that pottery making represented '...the earliest conscious utilization by man of a chemical change...', and went on to suggest that the ceramic vessels were the universal characteristic of Neolithic farming communities and the markers of their cultural identity.
More recently it has been suggested that early pottery actually occurred first in hunter-gatherer contexts in Eastern Eurasia, where it was associated with small-scale sedentary or semi-sedentary communities. Currently, the earliest known dates for ceramic vessels are from Southern China, where the direct dating of pottery at Miaoyan and Yuchanyan sites, based on insoluble residues, yield ${ }^{14} \mathrm{C}$ values of 17200 16300 calBC (15220 \pm 260 BP [BA94137b]) and 16 150-15 400 calBC respectively (14390 $230 \mathrm{BP}$ [BA95057b]) (Zhao and Wu 2000.236-237; Pearson 2005.823). In the Russian Far East very early pottery found was also produced by hunter gatherer societies at the sites of Gromatukha and Gasya and has been dated to between 14560-13070 calBC (13 $240 \mathrm{BP} \pm 85$ [AA-20939] and 14 160-12530 calBC (12 960 \pm 120 BP [LE-1781] (Kuzmin 2002.41,Tab. 1; Zhushchikhovsaya 2005.13,17). Kuzmin, on contrary suggests there was an almost simultaneous appearance of pottery in Southern China at c. 13700$13300 \mathrm{BP}$, in Japan at c. $13500 \mathrm{BP}$, and in the Russian Far East at c. 13300 BP (Kuzmin 2006.362371; see also Keally et al. 2004.349).

It was hypothesized that the earliest pottery was fired at less than $250^{\circ} \mathrm{C}$ (Pearson 2005.823) or at about $350^{\circ} \mathrm{C}$ (Zhushchikhovsaya 2005.14-15). This seems unlikely, as vessels fired below $350^{\circ} \mathrm{C}$ are not appropriate for boiling food, the presence of which has been confirmed by organic residues. The earliest vessels are described as deep bowls, with flat or pointed bases, with walls up to two centimetres thick. The estimated volume of the pots is approximately 5.5 to 6 litres. The secondary burning, carbonized adhesion, soot and water lines seen on many fragments, show that the basic functions of the pottery were for boiling water and food or other organic materials $\left(\delta^{13} \mathrm{C}\right.$ values are closest to $\mathrm{C} 3$ plants and herbivore meat) and extracting fish oils from salmonids (Keally, Taniguchi and Kuzmin 2003.5; Kuzmin 2002.42; Zhushchikhovsaya 2005.15, 29). These data correspond well with the concept of 'hearth-centred fe-male activities' that stem from increased levels of group sedentism, and are linked to an increasingly gendered focus of food processing and cooking, centred at/or around the hearth (Haaland 1997.381).

In recognising that the production of fired-clay vessels has an extended history, we must acknowledge that the emergence of this technology may not necessarily have been related to the technical and economical trajectories and dynamics of the transition to farming (see below), as had been suggested by Childe. 
It is increasing clear that diverse forms of ceramic technology had been 'inhabited' into the agency of Eurasian hunter-gatherers long before the emergence of sedentary social structures appeared. Moreover, these hunter gatherer ceramic technologies included not only vessels, but also the much older practice of making figurines from fired clay. In fact, the earliest European ceramic assemblages consist of anthropomorphic and zoomorphic figurines, pellets, 'earplugs' and 'structural ceramics' rather than pottery vessels, and have been dated to the Pavlovian, a local variant of the Eastern Gravettian techno-complex, dated to about 26000 BP (Verpoorte 2001. 80).

\section{Why ceramic vessels?}

To answer the question 'Why clay pots?' Brian Hayden $(1995 ; 2001 ; 2003)$ has suggested an economically oriented socio-political scenario, based on the interconnected concepts of 'private ownership', 'economically based competition' and 'prestige technologies' which appeared among complex hunter-gatherers and early farmers. He hypothesised that ceramic vessels were first created to impress guests at communal feasts. Pottery could be made in unusual forms and decorated in different ways, making it an ideal medium for the host to accrue prestige by serving food and drink during the event.

Hayden argued that the emergence of pottery as a 'prestige technology' can be linked to the critical economic distinction between 'generalized' and 'complex' hunter-gatherers. While sharing food is an absolute obligation among the former, the private ownership of stored food and the competitive use of food resources together with socio-economic inequalities are characteristic of the latter, trans-egalitarian societies. Hayden (1995.258) suggests that:

"Once technologies evolve to the point where private ownership and economically based competition can be sustained without immediate detrimental effects, it seems that some individuals in every community attempt to aggrandize themselves and to acquire material, social and political benefits for themselves and their families."

Their advantage was maintained through competitive feasting during which aspiring 'aggrandizers' could display their wealth, power and prestige, thereby signalling their successes and attracting new followers, but also through acts of conspicuous redistribution which would generate social debts in the wider collective towards the emerging leader. The crowded and intensely social nature of communal feasting represent ideal conditions for bringing selected products and substances into the focus of wider attention. The vessels used to prepare and serve these foods and beverages would also serve as a powerful means of advertising the prestige, wealth and influence of the event sponsor.

It has been suggested repeatedly that the emergence of social ranking in the farming communities of the Early Eurasian Neolithic grew out of cycles of competitive feasting. These became closely linked to both agricultural intensification, and the desire to produce more exotic foods (for example, domestic animals and cereals), as well as to the increasingly widespread production and use of ceramic serving bowls. The quantity, shape and size of pots associated with luxury foods formed an important indicator of household status (Hayden 2001.59; 2003.458-469; see also Van der Veen 2003.405-427). While the presence of large vessels may point to the occurrence of communal feasts, a change from large communal pots and serving bowls to the use of individual plates and drinking vessels may also point towards a shift away from eating from a communal bowl to the consumption of individual portions.

This 'competitive feasting' hypothesis for the emergence of agriculture was based on ethnographers' observations of trans-egalitarian societies in which "the primary force behind intensified subsistence production is not food shortage, but the desire to obtain social and political advantages - to obtain the most desirable mates, to create the most advantageous alliances, to wield the most political power" (Hayden 2003.465).

We must note, however, that domestic foodstuffs as luxury foods and the use of ceramic vessels as serving pots do not necessarily have to occur together (if at all) in contexts of transition to farming. The social dynamics of feasting can produce trans-egalitarian societies with or without the presence of either farming or pottery, and as the ethnographic parallels show that 103 of 862 non-sedentary and non-agricultural societies were pottery-making (cfr. Rice 1999.28).

\section{Why so many ceramic figurines and why the absence of ceramic vessels in the West Asian Pre-Pottery Neolithic?}

The first occurrence of ceramic vessels in Western Eurasia at circa 6900-6800 calBC marks the transition from the Pre-Pottery Neolithic C (PPNC) to the 
Pottery (or Late) Neolithic. The earlier pottery assemblages consist of coarse-wares, which are planttempered and undecorated. Several centuries pass before the emergence of elaborate painted styles and diverse shapes, which suggests that pottery had acquired a much wider significance in wider social contexts (Le Mière et Picon 1999.5-26; Aurenche et al. 2001.1197; Akkermans et al. 2006.123-156; Koztowski and Aurenche 2005). However, the knowledge of firing clay was older than the first pottery vessels. We see the production of fired ceramic female and animal figurines from the very start of PrePottery Neolithic (PPNA), at about 10200 calBC onward, although these were being produced alongside 'white ware' vessels of carved sandstone, alabaster and marble.

The Early Neolithic is marked by a series of inter-related changes in subsistence practices, economic systems, the emergence of built environments, and in the formalization of ritual and religious practices.

These diverse trajectories culminate in the Middle, Late and Final Pre-Pottery Neolithic B (PPNC) periods that span c 9800-7300 calBC. In this period the estimated mean site size increases dramatically from 3 to 12 hectares, with shifts in the control of resources into centralized larger settlements, and increasing population aggregation into regional centres. These transformations in the built environment also reflect ideological trajectories in two social domains, the first, in the rise of monumental 'public structures', and second, with 'ritual' architecture placed both inside and outside settlement boundaries. Most ritual buildings of this period were constructed with unique architectural features. They often appear to have been situated in highly visible locations and physically separated from residential areas. The residential area is marked by a shift from oval to smallscale sub-rectangular architecture to standardized rectangular multi-roomed buildings. Buildings were constructed, some with two floors, of stone and/or unfired mud brick in tandem with coloured lime-plaster floors which curved up to the walls. The very small size of the cells suggests they were used for storage and other facilities. Geometrically shaped ceramic objects - counting tokens - were found in some of these settings at Ain Ghazal, Mureybet, Cheikh Hassan, Tell Aswad, Tepe Asiah, Tell Ramad (SchmandtBesserat 1992.168, 170-171; Iceland, on line).

While there is evidence for domesticated caprines at some Middle PPNB settlements, by the end of the Late PPNB domesticated species including goat and sheep, pig and cattle, provided the evident bulk of meat protein. Herding emerged in the context of crop cultivation, and an 'intensive mixed farming' was well suited to the provisioning of nuclear households. Culling patterns for ovicaprines reflect a strategy of keeping animals primarily for meat production rather than dairying. It has been suggested that the economic practices of small-scale herding and the close control of herds in the vicinity of settlements, rather than the keeping of extensive, loosely controlled herds, would fit well with a relative degree of household autonomy (Flannery 2002.417433; Byrd 2000.63-98; Wright 2000.89-121; 2005; Bogaard 2005.184-198).

In these early farming communities mortuary, ritual and cultic practices, as well as the lack of obvious material differentiation among individual burials, have all been interpreted as evidence that the community was practising the intentional homogenization of community members at times of death, which may have emerged as a strategy for minimizing differences and tensions within communities and between households at a time of emerging social and economic differentiation. These community rites are also believed to have included both primary and secondary mortuary rituals which involved skull removal and plastering. In addition to these practices, there is evidence that large plastered statues were being produced, some about half life-size, which were displayed in upright positions within public structures (Goring-Morris 2000.103-136; Kuijt 1996.313336; 2000.75-102; 2001.80-99; Kuijt, Goring-Morris 2002.361-440). These practices persist over 3000 years and the high-profile nature of these public ceremonies suggest both a degree of community cohesion, as well as the persistence of a common underlying belief system.

There are hints, however, that certain individuals were afforded special treatment after death, perhaps an indication of the growing tensions between community cohesion, growing social differentiation and the emergence of individual power. The skulls of certain young males are removed post-mortem and subjected to plastering, moreover, many of these skulls also display specific morphological (brachycephalic) tendencies, perhaps resulting from in vivo skull deformation. The skull plastering practices demonstrate that the communities already had a sophisticated knowledge of 'pozzuolanic reaction', which is believed to be the domain of potters in creating hard, resistant and long-lasting clay products (Goren, Goring-Morris and Segal 2001.671-690). Whether 
the practitioners also had other special leadership or other symbolic roles, such as organizing planting, herding, harvesting, and the building of monumental public and ritual structures remains speculation. For example, Brian Hayden has suggested that these individuals were being commemorated as 'successful aggrandizers' (see above), but they may have served as 'shamans', or members of a ritual elite who possessed the necessary authority to impose economic order and a sense of social cohesion and collective identity (Rollefson 2000.183-186; Kuijt and Goring-Morris 2002.361-440; Lewis-Williams (2004. 28-59; 2005; Bischoff, on line).

In addition to the plastered skulls and stone figurines thousands of small ceramic (fired clay) female, male and animal figurines have been recovered from West Asian Pre-Pottery Neolithic sites (Figs. 3 and 4). In Levantine and South-eastern Anatolian sites these artefacts were deposited within the residential architecture, and may be connected to household cult practices. Many of the ceramic animal figurines also appear to have been ritually killed by stabbing with pieces of flint before the clay was fully fired (Rollefson 1986.5-52; 2000.167-168; Hauptmann 1999. 77; Hauptmann online; Voigt 2000.253-293; Cauvin 2000.105-120; Kuijt, Goring Morris 2002. 389). Human figurines were carefully handled but almost all were found in broken state as heads or as bodies. Some were deposited in ashy deposits within the roasting pits, and it was suggested they were intentionally destroyed as exploded in an uncontrolled firing which might be taken to reflect ritual death at the decease of the figurine's owner (Rollefson 2000. 168; Voigt 2000.265).

It is important to note that in Western Asia pottery production had not occurred prior to the end of the

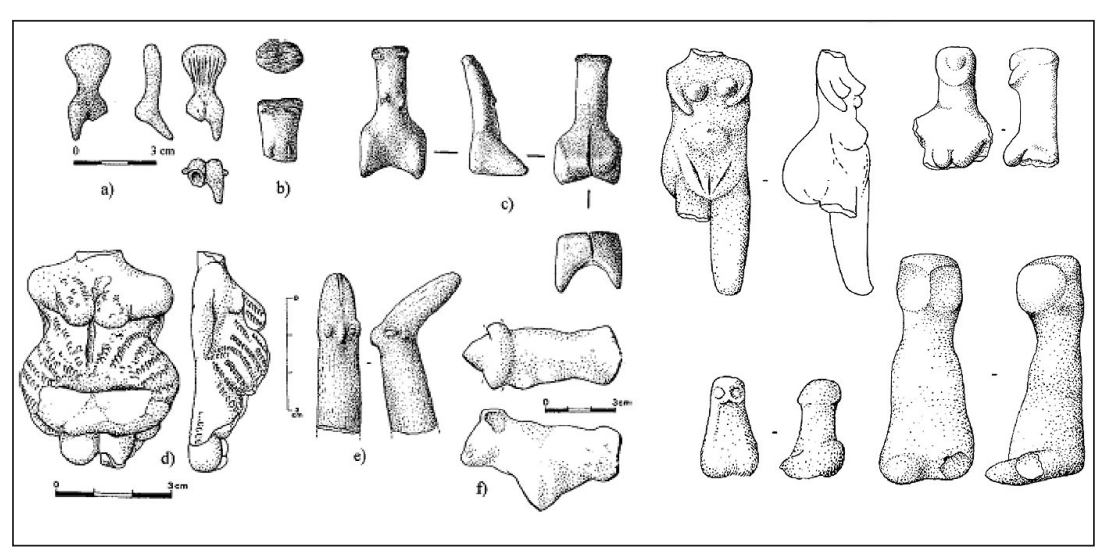

Fig. 3. Anthropomorphic and zoomorphic ceramic figurines in West Asian Natufian and Pre-Pottery Neolithic (from Kuijt \& Goring-Morris 2002.Fig.5 and Cauvin 2000.Fig. 8)
Pre-Pottery Neolithic (ca 6900-6800 calBC). Even after this point the manufacture and use of ceramic technology followed different trajectories in different areas; some communities remained 'aceramic' throughout, others adopted pottery at much later dates and only then in its more advanced rather than incipient form. Early pottery appears to have been types of container, which were used alongside 'white ware' and basketry.

Despite these regional variations we can note that the earliest appearance of ceramic vessels in West Asia correlates with the collapse of a 'ritual economy' and aggregation centres, the cessation of previous mortuary and ritual practices and the dispersal of peoples after the 'package' of crops and livestock had been adopted (Kuijt 2000.75-102). The beginning of pottery production may thus have been linked to the processes of settlement de-centralization, social fragmentation and, to the appearance of smaller communities or even autonomous households. The transition to small Pottery Neolithic households seems to follow scenario which anticipates the 'scalar stress' (Johnson 1982.322-333; see also Bandy 2004.322333 ), and the tensions between ritual and emerging economic elites, and between new forms of community cooperation, individual lineages (households) and traditional kinship organisation over rights and greater access to and control of resources and privileges, and in shaping social arrangements within communities in combination with regional environmental changes and local environmental degradation.

If earlier periods of the Pre-Pottery Neolithic had seen the activities of food preparation take place in more open arenas which facilitated wider social interaction and linked households, so later periods saw food preparation and storage facilities placed under greater control within the more private spaces of each household's architecture. This increasing 'privatisation' of storage, milling, cooking and eating that took place at the household level (Wright 2000.89-121; Bogaard 2005.177-196) may have been material manifestations of the social and status tensions referred to above. We may postulate that the process of social fragmentation and the cessation of commu- 
nal ritual practices also led to a shift away from the production of ceramics within a set of ritual acts, towards a 'secularisation' of the ceramic craft, which produced vessels used in more utilitarian roles. Within the newly emerging economically and socially autonomous household units we see the emergence of coarse and undecorated ceramic containers and vessels which became associated with food processing and consumption. Easy access to ceramic technology certainly initiated craft specialization and the much later appearance of 'potters marks' (Flannery 2002. 417-433).

In considering the history of the fired-clay techno$\operatorname{logy}$ in this region we may hypothesise that the earlier figurines were produced as part of a 'ritual economy' which had close links to household rituals and mortuary practices carried out in the hearth rooms and most secluded domestic spaces of the house. Less attention has been directed to reconstructing the form and content of much later rituals at sites like Catalhüyük and Asiklihüyük, and the extent to which ceramic technology might have been controlled by ritual practitioners, shamans is, of course, speculative, although early ceramic making could have been not only a prestige, but also a sacred craft, controlled by privileged individuals or groups.

We may postulate the collapse of a 'ritual economy' and the apparent decrease in the manufacture and use of figurines marked the shift away from the production of ceramics within a set of ritual acts. Ceramic technology seems to become 'broadly available' with the emerging economic elites. When applied to vessel production it was clearly associated with food processing and consumption, and well embedded within new forms of community cooperation and more individual - household's access and control of food resources.

\section{The pottery and the transition to farming in the South-eastern Europe}

Seventy years ago Gordon Childe (1936) argued that ceramic technology and pottery were an almost universal characteristic of Neolithic farming communities, with pottery styles playing important role an indicator of cultural identity. This argument gained widespread support and there remains a lasting assumption that the appearance of pottery is one of the clearest markers of cultural and technological discontinuity between Late Mesolithic hunter gatherers and the farming societies of Early Neolithic. Moreover, the discovery of spatially restricted pottery ornamen-

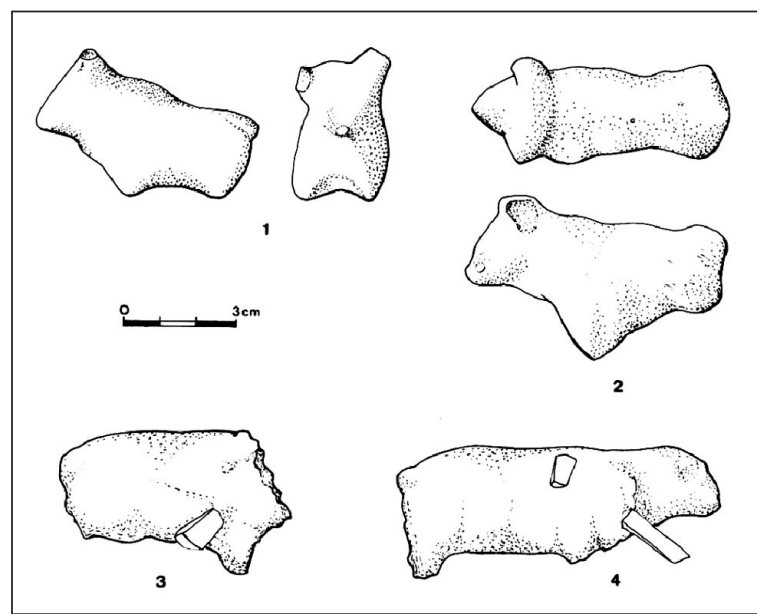

Fig. 4. Levantine Pre-Pottery Neolithic ceramic animal figurines pierced by flint bladelets (from Cauvin 2000.25, Fig. 38).

tation traditions pointed towards the dispersal of early farming and pottery making cultures out of Anatolia.

The linking of farming and pottery gave rise to 'centre and periphery' models of the origin and dispersal of farming communities. In these models finds of pottery have been employed as proxy indicators for determining the direction of farmer's migrations, and have been used to locate geographical boundaries marking out the line between advancing pottery-making farmers, and earlier hunter-gatherers, who were assumed to have had no prior knowledge of this technology. These interpretations are grounded in the assumption that Neolithic colonising populations brought an integrated 'package' of skills, technologies and languages with them when they crossed the border between the Levant and Europe.

If we look in more detail at early farming communities in South-eastern Europe we see that the role of pottery in these societies is more ambiguous. For example, in settlement contexts at Thessaly and Peloponnesus in South-eastern Europe, potters appear to have made few vessels, and that the pots do not show evidence of use on fires, and that the vessel volumes are too small for adequate storage Claude Björk (1995), Karen Vitelli (1993; 1999), Paraskevi Yiouni (1996), and Catherine Perlès (2001). In addition, annual pottery production has been estimated at between 12 to 13 pots at Franchthi and 7 to 22 pots at Nea Nikomedei (Perlès 2001.214). These insights suggest that pottery was not a mundane form of vessel technology in widespread day-to-day, but rather, that pottery appears to have the characteristics of 'elite goods' with special meanings and values. 
More recently, for example, Vitelli (1993.213-219; 1999.184-198) has suggested that these early ceramic vessels were produced for, and used in, shamanistic ceremonies, for a number of the highly decorated saucers and plates show evidence of burning incense or narcotic substances. These point to their manufacture for special public occasions and ceremonies. Vitelli also argues that these vessels were probably made by female shamans who had the restricted knowledge of pottery technology, as well as a deep understanding of how to use the medicinal and narcotic properties of plants to produce altered states of consciousness and relief from pain, perhaps during public ceremonies. These specialist vessels are chronologically embedded in the period of ca 7050-6450 calBC (Perlès 2001.84-92; Reingruber and Thissen 2005 on-line).

In the Danube Gorge in the Northern Balkans the earliest pottery was well embedded in local architectural traditions and closely associated with social and symbolic hunter-gatherers' practices. A series of mortuary and domestic palimpsests at Lepenski Vir, Padina and Hajdučka Vodenica provide a useful window onto the agency of social and spiritual interactions, practices and ritual landscape. I have argued elsewhere that pottery was a new form of materiality that was adapted by local complex hunter-gatherers, and as such should be understood as a material medium which was intentionally incorporated into rituals and feasting practices which upheld and reproduced across generations the communal perception of cosmological systems (Budja 2004; 2005).

The uniformity of the constructed spaces and internal structures at the complex hunter gatherer sites of Lepenski Vir, Padina and Hajdučka Vodenica is striking, and points towards a shared set of values, tastes and practices. The buildings consist of trapezoidal structures whose interior floor is mortared with limestone, with rectangular hearths made of vertical stone slabs are positioned in the centre. The interiors are also decorated with figurative stone statues and boulders sculpted in complex designs and coloured in red and black. They are placed on the floors primarily at the rear of the hearths. In addition, many of these sculptures were found in association with primary and secondary human and animal burials, which were placed under the floors (Radovanović 1996; Borić 1999; 2002a; 2002b; 2005).

Over seventy of these structures, which have variously been described as 'houses' or 'shrines', have been reported from the site of Lepenski Vir. Pottery was found in some of the structures, and the pots found in two deserve further discussion due to its obvious association with a series of other artefacts. In the first, the pot was recovered from structure 54 (Fig. 5), which is centrally located within the rest of the structures. The pot itself is decorated with two

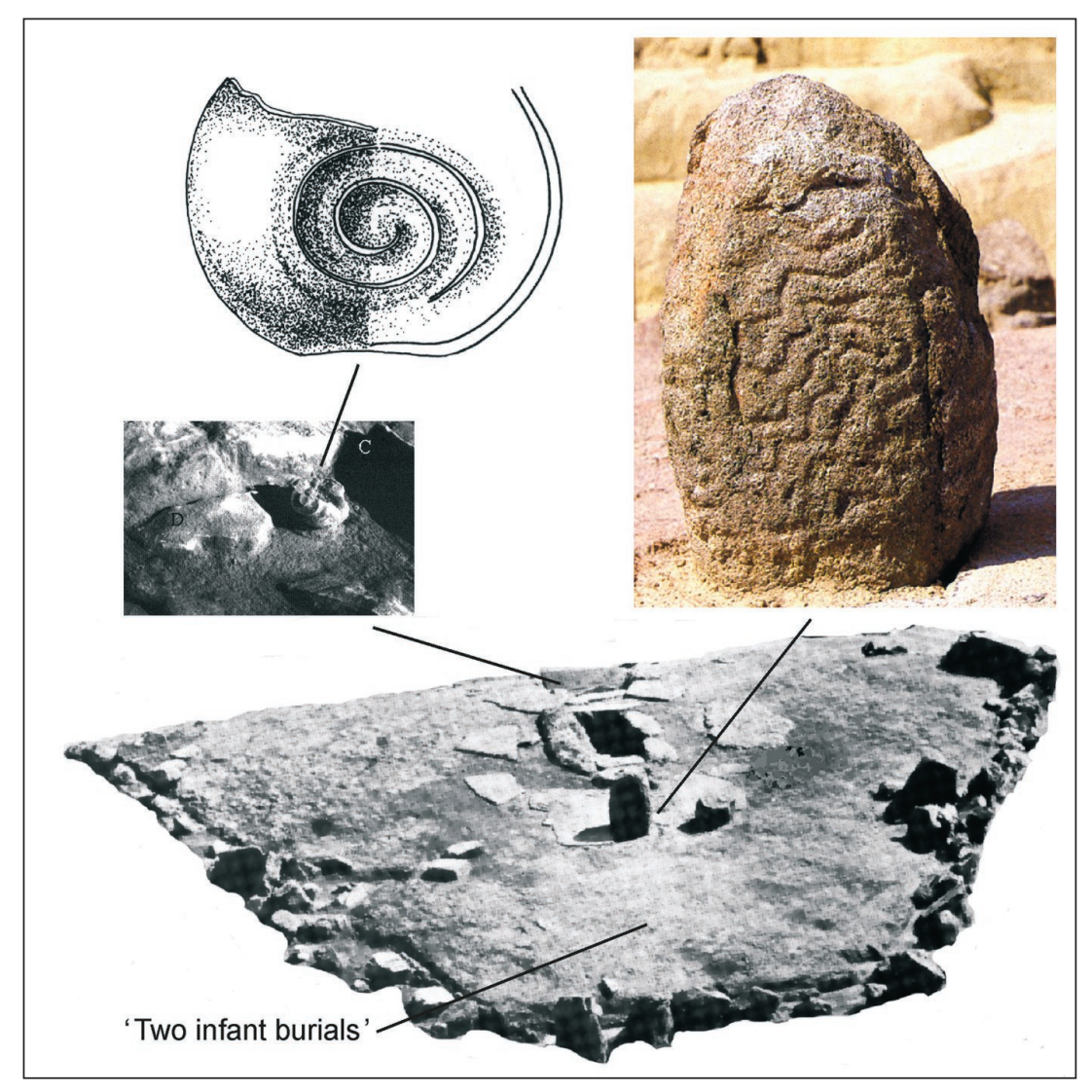

Fig. 5. In the centrally positioned trapezoidal built structure 54, a pot decorated with two plastic spirals placed on the two opposing sides of its body was associated with newborn and infant burials at the rear, the secondary burial of the mandible of a mature woman (within the hearth), and carved and coloured boulders and mortar (from Srejović \& Babović 1983.8, 18, 92-93, 167; Garašanin \& Radovanović 2001.Figs. 1-3). The structure was dated to ca 6430-5980 calBC (at 2 $\sigma$ )(Whittle at al. 2002. 67; Borić et al. 2004.235). 
plastic clay spirals which had been joined on to opposing sides of the vessel before firing. The pot was associated with new-born and infant burials located towards the rear of the house, as well as with the secondary burial of the mandible of a mature woman, which was located under the hearth, and finally with two carved and coloured boulders and mortar. In the second 'house' the peripherally located structure number 28 (Fig. 6), the pottery was closely associated with three child burials, one with an absent skull. The entire burial was covered by a large stone plate with two flanking sculpted boul-

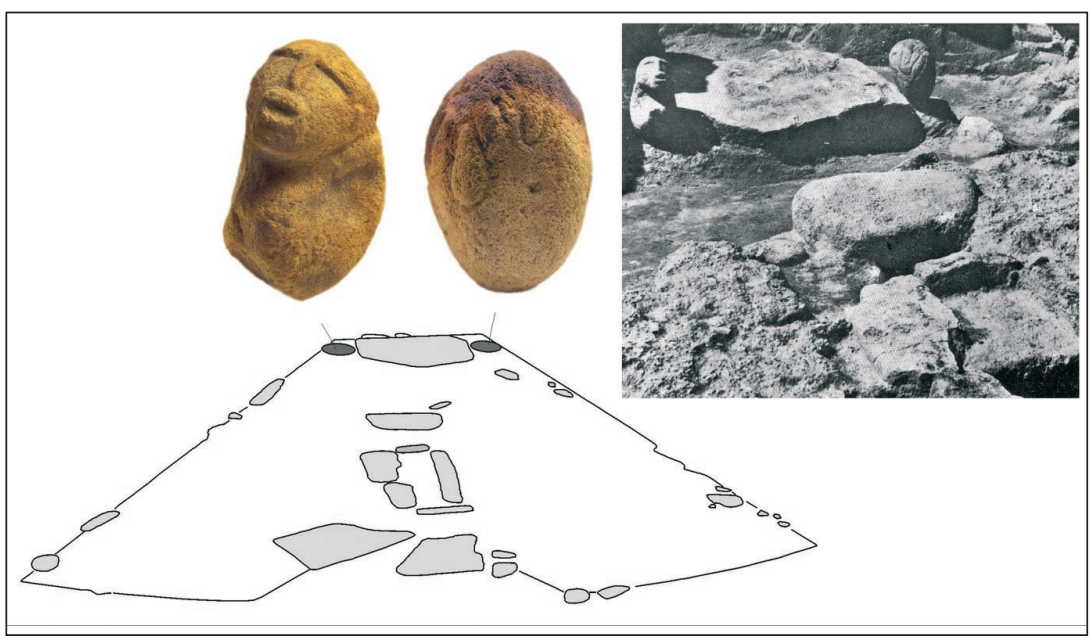

Fig. 6. In the trapezoidal built structure 28, pottery was contextually associated with three child burials, one with the skull absent, covered by a large stone plate with two flanking sculpted boulders at its sides and a huge red deer skull with antlers (from Srejović \& Babović 1983.69, 85, 107, but see also Dimitrijević 2000.113-114; Borić 2005.59-60; Stefanović and Borić 2004.539; Radovanović 1996.183).

ders at its sides and a huge red deer skull with antlers placed on the floor (Dimitrijevic 2000.113-114; Boric 2005.59-60; Stefanović and Borić 2004.539; Radovanovic 1996.183). It is worth noting first, that there is no evidence that domesticated crops and animals were being used at the site, although farming practice had already been adopted in the region, and second, that the first structure can be dated back to as early as ca 6430-5980 calBC (at 2 $\sigma$ ) (Whittle at al. 2002.67; Borić et al. 2004.235).

The situation at the contemporary site of Padina is slightly different. There is no clear evidence of burials within the trapezoidal built structures, and "the floors of these houses, made of a hard coating of burnt earth, do not show any noticeable damage or repairs corresponding to the position of the burial pit" (Jovanovic 1972.53). Nonetheless, the houses are stratigraphically, and to some extent chronologically well-related to the burials and mortuary structures at the site. Interestingly, the palimpsest of the burials is chronologically embedded in a considerable 'time depth' from 9965-9275 to 5780-5560 cal $\mathrm{BC}($ at $2 \sigma)$. In contrast, the sequence of ${ }^{14} \mathrm{C}$ dates of trapezoidal structures is available in fragments, as research interest seemed to be focused on selected burial contexts and related individual diet and palaeodietary patterns mainly. Only three of twenty-one trapezoidal built structures and associated contexts are dated, and are fixed to between 6410-6090 and

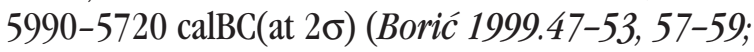
Whitle et al. 2002.92; Borić and Miracle 2004.341371; Boric et al. 2004.221-248). In total, fifty-two individuals have been found buried within the wider site, some incorporated into four distinct levels of a stone burial mound, others located below the trapezoidal structures, and some in secondary burials (for example, a skull with pebble and boulder cover). Four burials consist of individuals in a sitting position with legs crossed (Jovanović 1969(1971).32). Two of these seated bodies were walled into a conical stone structure up to the skull. Over this a monumental carved boulder with complex designs was positioned 'at the upper level' of the stone burial mound, and over the skulls. Although these stone constructions appear to be spatially well connected with the two trapezoidal built structures, there are no ${ }^{14} \mathrm{C}$ dates available for the latter, making conclusions about the chronological and structural interrelations between these features speculative (Jovanović 1969(1971).24-38; 1972.53; 1974.1-22; 1987. 1-16; Borić 1999.49-70; Roksandić 2000.26-27; Borić and Miracle 2004.Figs 2-3) (Fig. 7).

Across the Padina site, similarly to the Lepenski Vir, complete pottery vessels were found on the floors deposited within the trapezoidal built structures, and contextually associated with carved and painted pebbles and ornamented boulders. One of the most interesting pottery finds consists of small cups and bowls, a square dish on a low pedestal and a rhyton. In their form and scale they appear to be inappropriate for the household, and too small, and too unusual for routine domestic activities. As a result it has been suggested that they were perhaps 'prestigious serving dishes' (cfr. Radovanović 1996a.43; Borić 


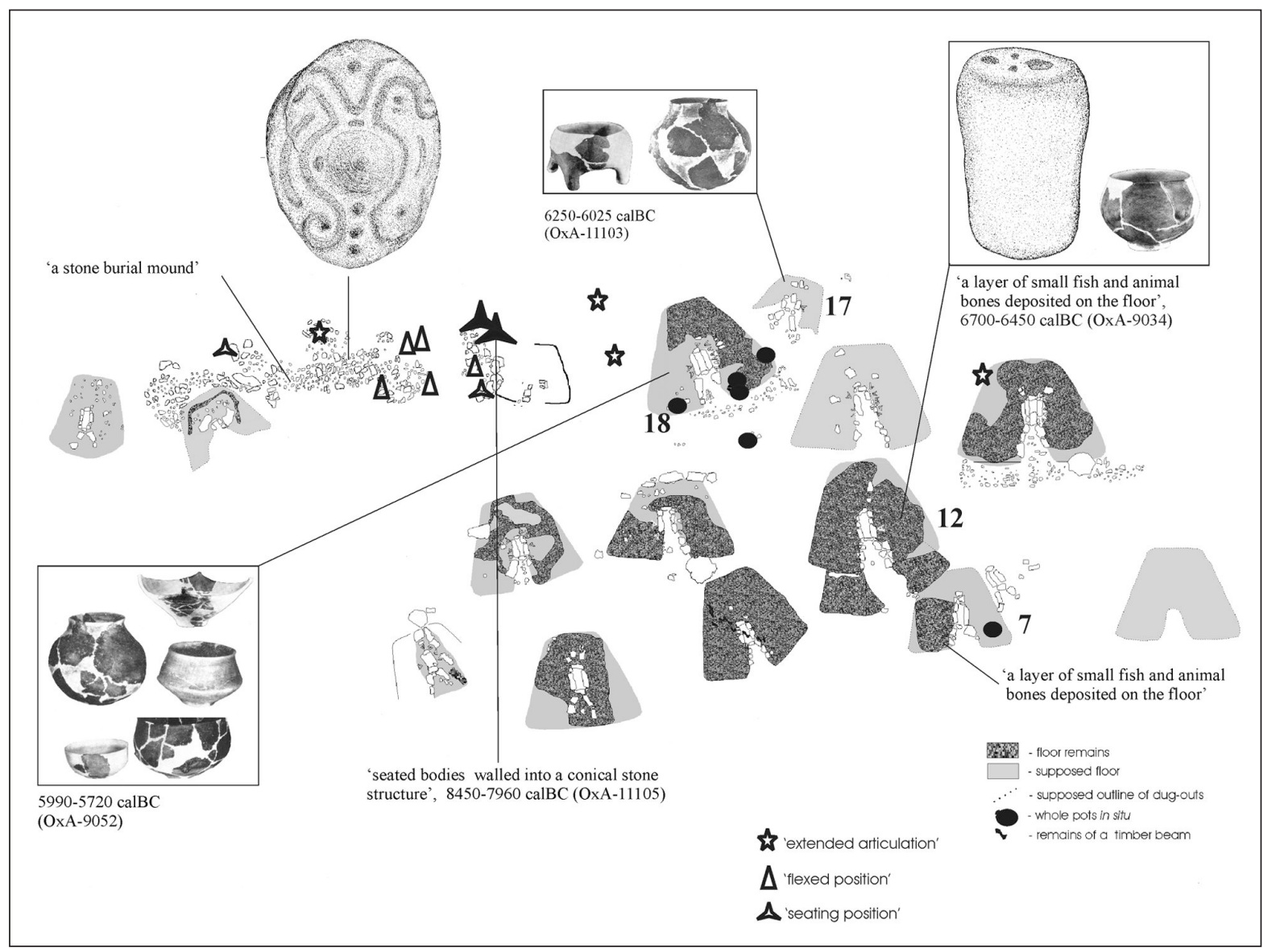

Fig. 7. Trapezoidal built and mortuary structures at Padina (from Jovanović 1969(1971); 1972; 1974; 1987; Borić 1999; Borić and Miracle 2004).

1999.53). The second interesting set of pots was found on the floor of trapezoidal structure number 12 , and is associated with a decorated boulder, and covered 'by a layer of small fish and animal bones' (Jovanović 1969(1971.30) (see Fig. 7). ${ }^{14} \mathrm{C}$ dates fix the pottery sets in structures 12,17 and 18 within the period of 6700-64501, 6250-6025 and 59905720 calBC (at $2 \sigma)$ (Boric and Miracle 2004.347, 350 ).

At the third, contemporaneous site of Hajdučka Vodenica in the micro region, pottery was reportedly linked to an elongated stone construction composed of a rectangular 'hearth', large plates of stone, with red burned flooring and a carved boulder. A few individual burials had been placed beside the hearth and had been covered by stone plates. In addition, a group of twenty-seven skeletons and a secondary skull burial were embedded inside the 'grave chamber' and are suggested to have identified and objecti- fied the associated mortuary structure, which was located by the side of the built structure. The excavator points out the fact that a stone axe and deer skull and antlers were placed beside the deceased inside the 'grave chamber'. The mortuary structure is dated to 6500 to 6090 calBC (at $2 \sigma$ ) (Radovanovic 1996.219-222; Borić and Miracle 2004.357-361).

In summary, we can suggest that when pottery vessels were placed on the trapezoidal floors of the structures found at Lepenski Vir Padina and Hajdučka Vodenica, these ceramic containers were being actively incorporated into the local, whether huntergatherers' (Lepenski Vir) or supposedly farmers' (Padina, see note 4 below) mortuary and ritual complexes. In addition, the use of pots appears to be embedded into wider enduring symbolic practices and associations, which include the re-construction of similar architectural structures, the practice of primary and secondary burials, the placing of inhumations in

1 The date acquired from the dog bone was not corrected for the freshwater reservoir effect, as suggested in Boric and Miracle (2004.

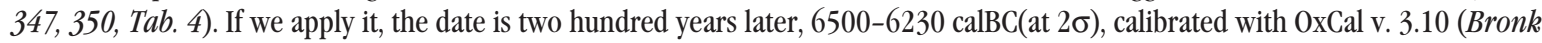
Ramsey 2005) and $220 \pm 23$ years correction applied. 
the sitting position, and associated suite of distinctive artefacts that include carved and painted boulders and mortars, the use of horned skulls of a large wild bovids, and the placing of deer skulls with a huge antlers.

In the Balkans and Transylvania these artefacts, structures and symbolism maintained a long tradition. The sculpted boulders were embedded in burials as well as in domestic contexts, and some were placed on ceramic pedestals and stone plates, for example, in the Early Neolithic settlement at Gura Baciului (Vlassa 1972.187-191; Lazarovici and Maxim 1995.379). Children buried in the sitting position were incorporated into Early Neolithic settlement contexts at Velesnica and Obre I, and a large deer skull and infant burial were placed in a centrally positioned trapezoidal pit-dwelling structure at Blagotin-Poljna. In addition, a horned auroch skull was placed at top of a female body in a burial in a pitdwelling at Golokut. ${ }^{4} \mathrm{C}$ dates indicate that these traditions continued into contexts in which farming was present: Blagotin, 6230-6030; Obre 2 5730-5520; Golokut, 5620-5470 calBC $2 \sigma$ (Whittle et al. 2002. 66, 70-71; Benac 1973.27-28,35; Gimbutas 1974. 19; Borić 1999.26-27; Radovanović 1996. 223).

Several new interpretations of settlement, mortuary and ritual complexes in the Northern Balkans have been published in the last decade. Some have focused on the dialectic opposition and symbolic confrontation between 'culture and nature' as part of a wider process which led to the 'the domestication of society', others have discussed the role of 'apotropaic power and potency', and 'body metamorphosis and animality'. In Hodder's (1990.21-31, 41-43) reading, the trapezoidal structures are seen as the locus, agency and habitus' within which hunter-gatherers were able to domesticate themselves, their ancestors and their 'wild' surroundings. In order to undertake this symbolic process of domestication they performed inhumations of ancestral bones and the dead, and installed into the domesticated setting of the home stone sculptures and statues, which represented wild fish-like ancestors.

In contrast, Borić (2002b.46-74; 2005.35-69), argues that the huge sculpted boulders commemora- ted particular individuals as much they commemorated the domestication of a wider 'realm of the dead and an-cestors' and 'cognitive logic of animality' which was practiced by hunter-gatherers and farmers in Northern Balkans.

A third interpretation has suggested that the large stone boulders, which were decorated with sculpted representations of fish-human beings, were material commemorations of the ' 8200 BP event', a global phase of climatic cooling that may have led to a rise in the Danube water levels leading to periodic flooding in the Danube Gorge. Bonsall et al. (2002(2003). 1-15) propose that neither the sculptures nor the mortar-floored buildings can be traced back before the catastrophic event, and when they appeared, they were intended to achieve dominance over the floods.

Despite these sweeping interpretations little attention has been paid to the specific symbols and conceptions attached to the boulders. Possibly, they may have been linked to altered states of consciousness, perhaps an important shamanistic element in the wider hunter-gatherer and early farmer cosmologies that were present in the Balkans. Correlations have been made between the boulders, petrogliphs and the cave paintings in the Balkans 3 , on the Adriatic and Ionian coast, where identical symbols and construals have been found in red and black on cave walls. These have identified as potentially entoptic motifs and iconography which might have been associated with altered states of consciousness, and wider shamanic beliefs, rituals and practices (Budja 2005.63-65).

While the Climente II and Gaura Chindei caves are located within the hunter-gatherers' site distribution in the Danube Gorge in Northern Balkans, the Cervi and Cosma caves are located a thousand kilometres to the south, near Porto Badisco at the Strait of Otranto. Some of the cave paintings demonstrate almost an identical canon in the realisating of red and black symbols and iconographies with those carved and engraved on sandstone boulders and sculptures in the Lepenski Vir deposited within the trapezoidal architecture and directly associated with the mortuary and ritual structures (Fig. 8). It is important to note that in the both caves, Cervi and Cosma at the

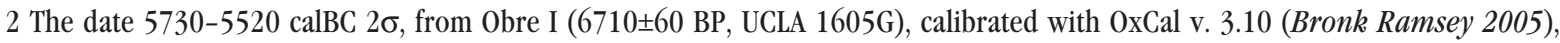
relates to the settlement context in which the burials were embedded.

3 In the Danube Gorge, paintings have been recorded in Climente II and Gaura Chindei (Boroneant 1977.23-34; 1999 on line), in Magourata Cave in the Northern Balkans (Anati 1971) and in Cervi Cave, near Porto Badisco (Otranto) at the Adriatic coast (Graziosi 1996). For the painted anthropomorphic figure with head-gear see also Devlet (2001.50-51).
} 
Adriatic coast, human burials, stone circles along the walls, containing cereals deposited on the floor, pits dug into the rocky ground with the Neolithic ceramic vessels deposited inside, were found (Griffoni Cremonesi 1994.179-197).

One of the most graphic narrative scenes is perfectly preserved in Cervi cave. The iconography of the painting (Fig. 9) on the left has a spiral motif and depicts figures with bows who appear to be hunting deer. To the right are what appear to be headless figures riding deer and bovids, and dancing with raised arms. Above the scene, a painted anthropomorphic figure with head-gear was placed (Graziosi 1996.117-119. Pls. 12-17). One possible narrative reading of the scene is that these are depictions of shamanistic practices, and associated mental experiences, which are associated with altered states of consciousness. When interpreting a similar frieze in Çatalhöyük, Lewis-Williams (2004.38-46, see also Lewis-Williams and Pearce 2005) suggested that in shamanistic societies the hunting of meat-producing animals is often linked to the belief that successful hunting requires the acquisition of the animals' supernatural powers. Moreover, the headless figures may well represent the dead, who may not merely have been present during the hunt, but might actually have been able to influence and assist in assuring a successful outcome. These ancestors, who in death may have departed to the other parallel world of spirits, may have acted as intermediaries between the animals' spirit masters and the actions of the humans in their desire to acquire animal power through hunting. Moreover, the severing of skulls from bodies may have related to the enactment of the ritualised 'death' and 'rebirth' of a shaman, and to his subsequent ability to travel between the realms of the lower and upper worlds. We may note that the spiritual experiences associated with the de-composition and re-constitution of the physical body may take place during neurologically-generated hallucinations generated by altered state of consciousness, the painted visualization of these experiences, whether through the medium of built structures or in cave tunnels, may have been driven by the desire to ritually (re)enact the core experiences through a complex ritualised setting, for example, as part of initiation into shamanism, which perhaps provided future practitioners with the necessary knowledge and skill, but also the social status and in some instances, the political influence which the post both required and commanded.

Returning now to the Northern Balkans we may hypothesise that the cosmological paradigm we noted above, in which distinctive burials and structured associations with other material artefacts were placed within the settings of the trapezoidal structures may have depicted a similar set of conceptions to those of shamanism and hunting as depicted in the cave art. For example, the skull of an old woman, the horned skull of a large bovid and the skull of a deer with antlers were placed beside the body of a man (Fig. 10); a headless child burial had been covered by a large stone plate with two flanking sculpted boulders at its sides and with a huge red deer skull with antlers on the floor (Fig. 7); finally, a skull of an older man was placed beside the body of child in a sitting position, whose legs were crossed (Radovanovic 1996. Fig 4.15).

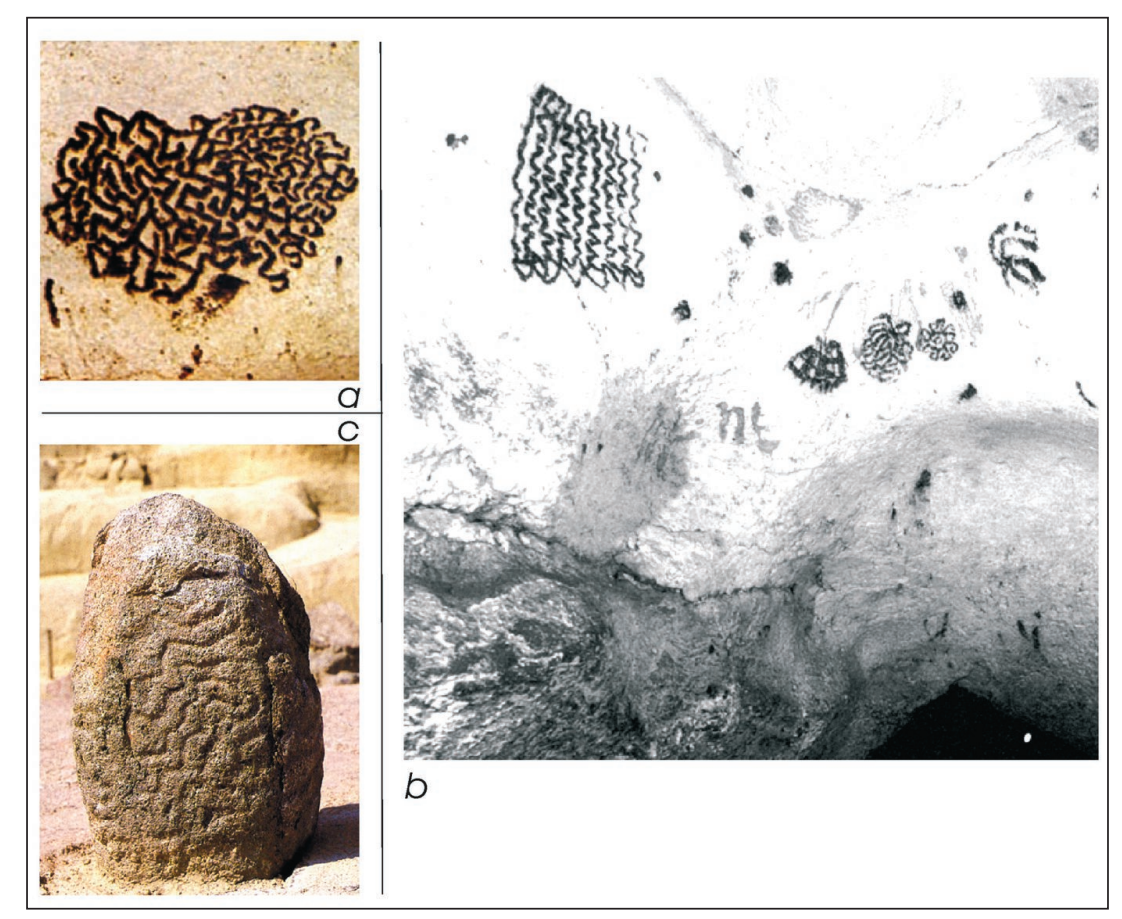

Fig. 8. The entoptic motifs and construals painted on the cave walls in Cervi cave near Porto Badisco ( $a$ and b) and carved and engraved on sandstone boulders and sculptures, deposited within the trapezoidal architecture and directly associated with the mortuary and ritual structures in the Lepenski Vir in Northern Balkans (c) (from Graziosi 1996.Pls. 70 and 72; Srejović \& Babović 1983.8). 


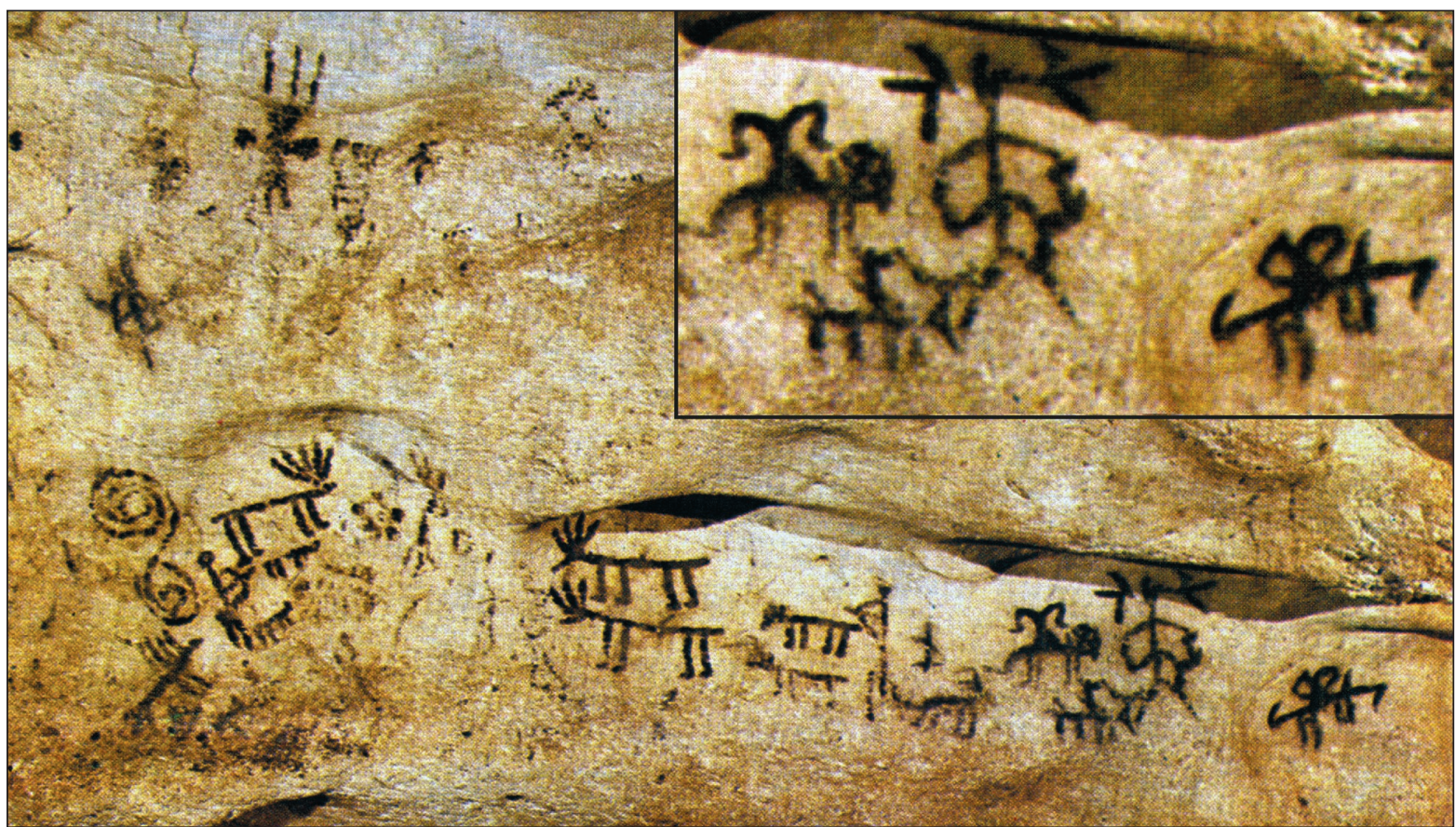

Fig. 9. The painted scene from in Cervi cave (Porto Badisco, Otranto). The iconography of the painting consist of a spiral motif and figures with bows who appear to be hunting deer on the left, and the headless figures riding deer and bovids, and dancing with raised arms on the right. Above the scene, a painted anthropomorphic figure with head-gear was placed. (from Graziosi 1996.P1. 12).

We may also hypothesise that, along with monumental boulders, the 'small cups and bowls, square dish on a low pedestal and rhyton' (see above), the 'layer of small fish and animal bones'4 which were deposited within these structures were all part of a ritualised set of practices which involved not only the bridging the world of the living and that of the dead', as suggested, but also included feasting and ritual communion and exchange with different realms of the cosmos. Like the shamanic soul-flight ritual, the feast provides a site, medium and context in and through which social relations could be symbolically negotiated and represented (Dietler 2001.65-114; Jordan 2004.117-134; Price 2001.3-16). In the case of the Northern Balkans these ritualised acts included the control of rites as well as mediation between the community and the supernatural. They were also caught up with the reproduction of social hierarchies and status, but also re-forged social networks within which the structural transformation of hunting and gathering communities was eventually leading to the advent of farming.

Within these local and regional settings it is clear that if pottery was an element of 'Neolithic' materiality it production, use and deposition was being actively and creatively incorporated within the endu- ring frameworks of pre-existing hunter-gatherers' social, domestic and mortuary structures. Within these contexts it was the agency of hunter gatherers which initiated and made possible both the later structural transformations in the economy, but also the almost simultaneous dispersal of a new form of ceramic materiality into the region. This scenario contrasts strongly with the Levant, where the adoption of pottery making seems have been caught up in processes of social decentralization and community fragmentation, which were part of the collapse of the 'ritual' elements in the Early Neolithic economy. Following this, pottery became contextualised within the more routinised practices of food processing and consumption that were part of the form and fabric of the new agricultural economy.

\section{Conclusions}

In recognising that the appearance of ceramic technology and production of fired-clay vessels has an extended history, we must acknowledge that the emergence of this technology has not necessarily been related to the technical and economical trajectories and dynamics of the transition to farming, as had been broadly accepted. It is increasing clear that diverse forms of ceramic technology had been 'inha-

4 Animal domesticates: Bos tauros, Ovis/capra and Sus domesticus have been reported from Padina (Clason 1980.141-173). 


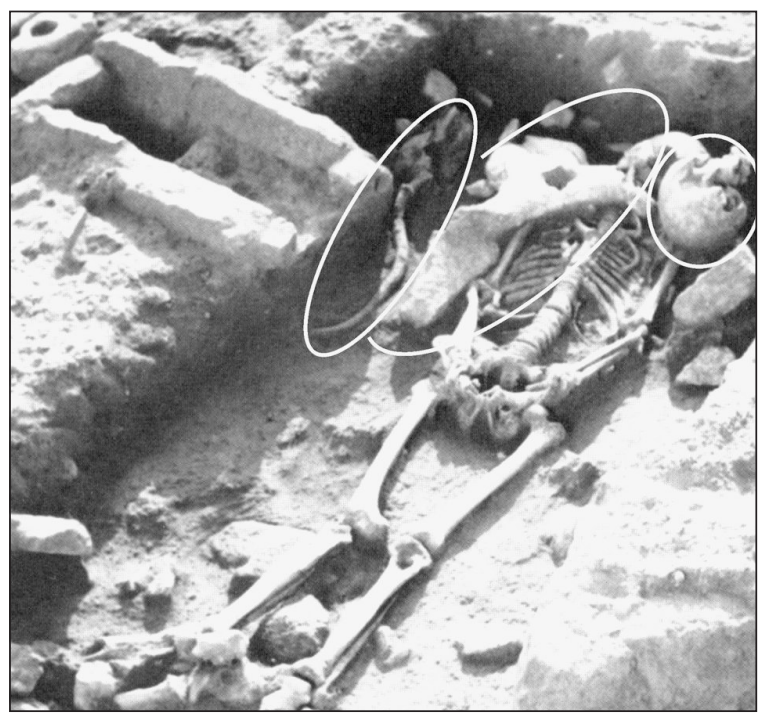

Fig. 10. Lepenski Vir, burial No 7 a (from Srejović \& Babović 1983.18 and Radovanović 1996.Fig 4.3). The skull of an 'old' woman, the horned skull of a large bovid and the skull of a deer with antlers were placed beside the body of a man.

bited' into the agency of Eurasian hunter-gatherers long before the emergence of sedentary social structures appeared. Moreover, these hunter gatherer ceramic technologies included not only vessels, but also the much older practice of making figurines from fired clay. The earliest European ceramic assemblages consist of anthropomorphic and zoomorphic figurines rather than pottery vessels, and have been dated to the Pavlovian, a local variant of the Eastern Gravettian techno-complex, dated to about $26000 \mathrm{BP}$. In fact, there were two very different and indeed independent technological trajectories in Western Eurasia, the first the use of fired clay to make figurines and later vessels, and second the plant and animal domestication and rise of agro-pastoral farming.

We suggest the ceramic vessel as serving pot is certainly not the part of 'competitive feasting' scenario for the emergence of agriculture in Levant since the domestic foodstuffs as luxury foods and the use of ceramic pots have not occurred together in contexts of transition to farming in the region. The fired-clay technology in Pre-Pottery Neolithic was restricted to the production of female, male and animal figurines and limited by the ideology of the 'ritual economy' which had close links to household rituals and mortuary practices. The earliest appearance of ceramic vessels there correlates with the collapse of aggregation centres, the cessation of previous mortuary and ritual practices and the dispersal of peoples after the 'package' of crops and livestock had been adopted. We may postulate the collapse of a 'ritual economy' and the apparent decrease in the manufacture and use of figurines led to a shift away from the production of ceramics within a set of ritual acts, towards a 'secularisation' of the ceramic craft, which produced vessels in more utilitarian contexts, linked to the emerging economic elites, and associated with the new forms of community cooperation and more individual, household's access and control of food resources.

This scenario contrasts with the South-eastern Europe where the adoption of pottery making was closely associated with social and symbolic hunter-gatherers' practices. The pottery seems to have been a new form of materiality that was adapted by local complex hunter-gatherers, and as such should be understood as a material medium which was intentionally incorporated into rituals and feasting practices which upheld and reproduced across generations the communal perception of cosmological systems and social networks within which the structural transformation in the economy become verified. It was the agency of hunter gatherers which initiated and made possible both the transition to farming, but also the almost simultaneous dispersal of a new form of ceramic materiality into the region.

\section{REFERENCES}

AKKERMANS M. M. G. P., CAPPERS R., CAVALLO C., NIEUWENHUYSE 0., NILHAMN B. and OTT N. I. 2006. Investigating the Early Pottery Neolithic of Northern Syria: New Evidence from Tell Sabi Abyad. American Journal of Archaeology 110(1): 123-156.

ANATI E. 1971. Maggourata Cave, Bulgaria. Bollettino del Centro Camuno do Studi Preistorici 6: 83-107.
AURENCHE 0., GALET P., RÉGAGNON-CAROLINE E., ÉVIN J. 2001. Proto-Neolithic and Neolithic cultures in the Middle East - the birth of agriculture, livestock raising, and ceramics: a calibrated ${ }^{14} \mathrm{C}$ chronology $12,500-5500 \mathrm{cal}$ bc. $R a$ diocarbon 43(3): 1191-1202.

BANDY S. M. 2004. Fissioning, Scalar Stress, and Social Evolution in Early Village Societies. American Anthropologist 106 (2): 322-333. 
BAILEY D. W. 2005. Prehistoric Figurines. Representation and corporeality in the Neolithic. London and New York. Routledge.

BENAC A. 1973. Obre I. Glasnik Zemaljskog muzeja Bosne i Hercegovine. N.s. 27/28. Arheologija: 5-171.

BIEHL P. F. 1996. Symbolic communication system: symbols on anthropomorphic figurines of the Neolithic and Chalcolithic from eouth-eastern Europe. Journal of European Archaeology 4: 153-176.

BISCHOFF D. 2002. Symbolic worlds of Central and Southeast Anatolia in the Neolithic Age, on-line http://www. canew.org/lecbischoffbox.html

BJÖRK C. 1995. Early Pottery in Greece. A technical and functional analysis of the evidence from Neolithic Achilleion Thessaly. Studies in Mediterranean Archaeology 115. Paul Åströms Förlag. Jonnsered.

BOGAARD A. 2005. 'Garden agriculture' and the nature of early farming in Europe and the Near East. World Archaeo$\log y$ 37(2): 177-196.

BONSALL C., MACKLIN G. M., PAYTON W. R., BORONEANT A. 2002(2003). Climate, floods and river gods: environmental change and the Meso-Neolithic transition in southeast Europe. Before Farming 4 (2): 1-15.

BORIĆ D. 1999. Places that created time in the Danube Gorges and beyond, c. 9000-5500 BC. In M. Budja (ed.), $6^{\text {th }}$ Neolithic Studies. Documenta Praehistorica 26: $41-$ 70 .

2002a. The Lepenski Vir conundrum: reinterpretation of the Mesolithic and Neolithic sequences in the Danube Gorges. Antiquity 76(294): 1026-1039.

2002b. 'Deep time' metaphor. Journal of Social Archaeology 3(1): 46-74.

2005. Body Metamorphosis and Animality: Volatile Bodies and Boulder Artworks from Lepenski Vir. Cambridge Archaeological Journal 15(1): 35-69.

BORIĆ D. and MIRACLE P. 2004. Mesolithic and Neolithic (Dis)Continnuities in the Danube Gorges: Nes Ams Dates from Padina and Hajdučka Vodenica (Serbia). $O x$ ford Journal of Archaeology 23(4): 341-371.

BORIĆ D., GRUPE G., PETERS J., MIKIĆ Ž. 2004. Is the Mesolithic-Neolithic subsistence dichotomy real? New stable isotope evidence from the Danube Gorges. European Journal of Archaeology 7(3): 221-248.

BORIĆ D. \& STEFANOVIĆ S. 2004. Birth and death: infant burials from Vlasac and Lepenski Vir. Antiquity 78(301): 526-546.
BORONEANȚ V. 1977. Arta rupestra dis peștera Gaura Chindei, Comuna Pescari (Judetul Caraş-Severin). Monumente Istorice si de ArtaRevista muzeelar şi manumentelor 1: 23-34.

1999, on line, The Mesolithic Habitation Complexes in the Balkans and the Danube Basin, Living Past 1, on-line http://cimec.cilea.it/livingpast/nr1/boroneant/mesoli thic.htm

BUDJA M. 2004. The transition to farming and the 'revolution' of symbols in the Balkans. From ornament to entoptic and external symbolic storage. In M. Budja (ed.), 11th Neolithic Studies. Documenta Praehistorica 31: 59-81.

2005. The process of Neolithisation in South-eastern Europe: from ceramic female figurines and cereal grains to entoptics and human nuclear DNA polymorphic markers. In M. Budja (ed.), 12th Neolithic Studies. Documenta Praehistorica 32: 53-72.

BYRD B. F. 2000. Households in transition: Neolithic social organisation within southwest Asia. In I. Kuijt (ed.), Life in Neolithic Farming Communities: Social Organisation, Identity and Differentiation. Academic/Plenum, New York: 63-98.

CAUVIN J. 1978. Les premiers villages de Syrie-Palestine du IXe au VIIe millénaire avant Jésus-Christ. Travaux de La Maison de l'Orient 4, serie archéologique 3. Maison de l'Orient. Lyons.

2000. The Birth of the Gods and the Origins of Agriculture. Cambridge University Press. Cambridge.

CHAPMAN J. 2000. Fragmentation in Archaeology. Routledge. London and New York.

CHILDE V. G. 1936. Man Makes Himself. Watts. London.

CLASON A. 1980. Padina and Starčevo: game, fish and cattle. Palaeohistoria 22: 141-173.

DEVLET E. 2001. Rock art ad the material culture of Siberian and Central Asian shamanism. In N. Price (ed.), The Archaeology of Shamanism. Routledge. London and New York: 43-55.

DIETLER M. 2001. Theorizing the Feast: Rituals of Consumption, Commensal Politics, and Power in African Contexts. In M. Dietler and B. Hayden (eds.), Feasts. Archaeological and Ethnographic Pespectives on Food, Politics, and Power. Smithsonian Institution Press. Washington and London: 65-119.

DIMITRIJEVIĆ V. 2000. The Lepenski Vir Fauna: Bones in Houses and Between Houses. In M. Budja (ed.), $7^{\text {th }}$ Neolithic Studies. Documenta Praehistorica 27: 101-117. 
FLANNERY K. 2002. The Origins of the Village Revisted: From Nuclear to Extended Households. American Antiquity 67(3). 417-433.

GIMBUTAS M. 1974. Chronology of Obre I and Obre II. Wissenschaftlichen Mitteilungen des Bosnisch-Herzegowinischen Landesmuseums 4. Archäologie: 15-35.

1989. The Language of the Goddess. Harper and Row. San Francisco.

GOREN Y., GORING-MORRIS A. N. and SEGAL I. 2001. The technology of skull modeling in the Pre-Pottery Neolithic B (PPNB): Regional variability, the relation of technology and iconography and their archaeological implications. Journal of Archaeological Science 28(7): 671-690.

GORING-MORRIS A. N. 2000. The quick and the dead: The social context of aceramic Neolithic mortuary practices as seen from Kfar HaHoresh. In I. Kuijt (ed.), Life in Neolithic Farming Communities: Social Organization, Identity, and Differentiation. Kluwer Academic/Plenum, New York: 103-136.

GRAZIOSI P. 1996. The prehistoric paintings of the Porto Badiso cave. Origines. Firenze.

GIFFONI CREMONESI R. 1994. Observations on the problems related to certain cult phenomena during the Neolithic in the Italian Peninsula. Journal of European Archaeology 2(2): 179-197.

HAALAND R. 1997. Emergence of sedentism: new ways of living, new ways of symbolizing. Antiquity 71(272): 37485 .

HANSEN S. 2005. Neolithic Figurines East-West. In C. Licter (ed.), How did farming reach Europe. Anatolian-European relations from the second half of the 7 th through the first half of the $6^{\text {th }}$ millennium calBC. BYZAS 2. Veröffentlichungen des Deutschen Archäologischen Instituts Istanbul. Istanbul: 195-212.

HAUPTMANN H. 1999. The Urfa region. In M. Özdoğan and N. Başgelen (eds.), Neolithic in Turkey. The cradle of civilization, new discoveries. Arkeoloji ve Sanat Yayinlari, Istanbul: 65-86.

Upper Mesopotamia in its regional context during the Early Neolithic, on-line http://www.canew.org/siteplan. html

HAYDEN B. 1995. The emergence of prestige technologies and pottery. In W. Barnett and J. Hoopes (eds.), The Emergence of Pottery. Smithsonian Institution Press. Washington DC: $257-266$.

2001. Fabulous feasts: a prolegomenon to the importance of feasting. In M. Dietler and B. Hayden (eds.),
Feasts: Were luxury foods the first domesticates? Archaeological and Ethnographic Perspectives on Food, Politics, and Power. Smithsonian Institution Press, Washington DC: 23-64.

2003. Were luxury foods the first domesticates? Ethnoarchaeological perspectives from Southeast Asia. World Archaeology 34(3): 458-469.

HODDER I. 1990. The Domestication of Europe. Structure and Contingency in Neolithic Societies. Blackwell Publishers. Oxford.

IAKOVLEVA L. 1999. The gravettian art of Eastern Europe as exemplified in the figurative art of Kostenki 1. In W. Roebroeks, M. Mussi, J. Svoboda and K. Fennema (eds.), Hunters of the Golden Age. The Mid Upper Palaeolithic of Eurasia 30,000-20,000 BP. University of Leiden. Analecta Praehistorica Leidensia 31: 125-133.

ICELAND H. Token finds at Pre-Pottery Neolithic 'Ain Ghazal, Jordan: a formal and technological analysis, on-line http://link.lanic.utexas.edu/menic/ghazal/Chap1/chapter1. htm

JOHNSON G. 1982. Organizational Structure and Scalar Stress. In C. Renfrew, M. Rowlands and B. A. Segraves (eds.), Theory and Explanation in Archaeology. Academic Press, New York: 389- 421.

JORDAN P. 2004. Examininig the role of agency in huntergatherer cultural transmission. In A. Gardner (ed.), Agency Uncovered. UCL Press, London: 117-134.

JOVANOVIĆ B. 1969(1971). Chronological Frames of the Iron Gate Group of the Early Neolithic Period. Archaeologica Iugoslavica 10: 23-38.

1972. The autochthonous and the migrational components of the Early Neolithic in the Iron Gates. Balcanica 3: 49-58.

1974. Praistorija Gornjeg Djerdapa. Starinar N.S. 22: $1-23$.

1987. Die Architektur und Keramik der Siedlung Padina B am Eisernen Tor, Jugoslawien. Germania 65(1): $1-16$.

KEALLY T. C., TANIGUCHI Y. and KUZMIN V. Y. 2003. Understanding the Beginnings of Pottery Technology in Japan and Neighboring East Asia. In Y. V. Kuzmin (ed.), The Nature of Transition From the Palaeolithic to the Neolithic in East Asia and the Pacific. The Review of Archaeology 24(2): 3-14.

KING R. and UNDERHILL P. A. 2002. Congruent distribution of Neolithic painted pottery and ceramic figurines with Ychromosome lineages. Antiquity 76(293): 707- 714. 
KOZŁOWSKI K. S., AURENCHE 0. 2005. Territories, Boundaries and Cultures in the Neolithic Near East. British Archaeological Reports IS 1362. Archaeopress, Oxford.

KUIJT I. 1996 Negotiating equality through ritual: A consideration of Late Natufian and Pre-Pottery Neolithic A Period mortuary practices. Journalof Anthropological Archaeology 15(4): 313-336.

2000. People and Space in Early Agricultural Villages: Exploring Daily Lives, Community Size, and Architecture in the Late Pre-Pottery Neolithic. Journal of Anthropological Archaeology 19: 75-102.

2001. Meaningful masks: Place, death, and the transmission of social memory in early agricultural communities of the Near Eastern Pre-Pottery Neolithic. In M. S. Chesson (ed.), Social Memory, Identity, and Death: Intradisciplinary Perspectives on Mortuary Rituals. American Anthropological Association, Archaeology Division,Washington DC, Vol. 10: 80-99.

KUIJT I. and GORING-MORRIS N. 2002. Foraging, Farming, and Social Complexity in the Pre-Pottery Neolithic of the Southern Levant: A Review and Synthesis. Journal of World Prehistory 16( 4): 361-440.

KUZMIN Y. V. 2002. The Earliest Centres of Pottery Origin in the Russian Far East and Siberia: Review of Chronology for the Oldest Neolithic Cultures. In M. Budja (ed.), 9th Neolithic Studies. Documenta Praehistorica 29: 3746.

2006. Chronology of the earliest pottery in East Asia: progress and pitfalls. Antiquity. Antiquity 80(308): 362-371.

LAZAROVICI G. and MAXIM Z. 1995. Gura Baciuliu. Biblioteca Musei Napocensis XI. Cluj-Napoca.

LE MIÈRE et PICON M. 1999. Les débuts de le ceramique au Proche-Orient. Paléorient 24(2): 5-26.

LEWIS-WILLIAMS D. 2004. Constructing a cosmos. Architecture, power and domestication at Çatalhöyük. 28-59; 2005). Journal of Social Archaeology 4(1): 28-59.

2005. Inside the Neolithic Mind. Consciousness, Cosmos and the Realm of the God. Thames and Hudson. London.

MAINA on-line. http://www.vm.kemsu.ru/en/palaeolith/ plastic/maina.html

MARANGOU C. 1996. Assembling, displaying, and dissembling Neolithic and Eneolithic figurines and models. Journal of European Archaeology 4: 177-202.
MARSHACK A. 1991. The female image, a "time-factored" symbol: A study in style and modes of image use in the European Upper Palaeolithic. Proceedings of the Prehistoric Society 57: 17-31.

MORGAN L. H. 1878. Ancient Society. World, New York.

PEARSON R. 2005. The social context of early pottery in the Lingnan region of south China. Antiquity 79(306): 819-828.

PERIČIĆ M. et al. 2005. High-Resolution Phylogenetic Analysis of Southeastern Europe Traces Major Episodes of Paternal Gene Flow among Slavic Populations. Molecular Biology and Evolution 22(10): 1964-1975.

PERLÈS C. 2001. The Early Neolithic in Greece. The first farming communities in Europe. Cambridge World Archaeology. Cambridge University Press. Cambridge.

PRICE S. N. 2001. An archaeology of altered states: Shamanism and material culture studies. In N. Price (ed.), The Archaeology of Shamanism. Routledge. London and New York: 3-16.

RADOVANOVIĆ I. 1996. The Iron Gates Mesolithic. International Monographs in Prehistory. Archaeological Series 11. Ann Arbor. Michigan.

REINGRUBER A. and THISSEN L. on-line. CANeW ${ }^{14} \mathrm{C}$ databases and ${ }^{14} \mathrm{C}$ charts. Aegean Catchment. (E. Greece, S. Balkans and W. turkey) 10,000-5,500 cal BC. http://www. canew.org/data.html

RICE M. P. 1999. On the Origins of Pottery. Journal of Archaeological Method and Theory 6(1): 1-54.

ROKSANDIĆ M. 2000. Between foragers and farmers in the Iron Gates Gorge: physical anthropology perspective. Djerdap population in transition from Mesolithic to Neolithic. In M. Budja (ed.), $7^{\text {th }}$ Neolithic Studies. Documenta Praehistorica 27: 1-100.

ROLLEFSON G. 0. 1986. Neolithic 'Ain Ghazal (Jordan): Ritual and ceremony II. Paleorient 12: 5-52.

2000. Ritual and Social Structure at Neolithic 'Ain Ghazal. In I. Kuijt (ed.), Life in Neolithic Farming Comunities. Social Opganization, Identity and Differentiation. Fundamental Issues in Archaeology. Kluwer Academic and Plenum Publisher, New York: 165-190.

SAXON E. C. 1976. Pre-Neolithic Pottery: New Evidence from North Africa. Proceedings of the Prehistoric Society 42: 327-329.

SCHMANDT-BESSERAT D. 1992. Before Writing. From Counting to Cuneiform. University of Texas Press. Austin. Volume 1. 
SEMINO 0. et al. 2004. Origin, Diffusion, and Differentiation of Y-Chromosome Haplogroups E and J: Inferences on the Neolithization of Europe and Later Migratory Events in the Mediterranean Area. American Journal of Human Genetics 74: 1023-1034.

SOFFER O., VANDIVER P., KLIMA B. and SVOBODA J. 1993. The Pyrotechnology of Perfomance Art: Moravian Venuse and Wolverines. In H. Knecht, A. Pike-Tay, R. White (eds.), Before Lascaux. CRC Pres. Boca Raton: 259-275.

SOFFER 0., VANDIVER P. 1997. The Ceramics from Pavlov I -1957 Excavation. In J. Svoboda and P. Škrdla (eds.), Pavlov I - Northwest (The Upper Paleolithic burial and its bettlement context. The Dolni Věstonice Studies 4: 383-401.

SOFFER O., ADOVASIO J. M. and HYLAND D. C. 2000. The 'Venus' Figurines. Textiles, Basketry, Gender, and Status in the Upper Paleolithic. Current Anthropology 41(4): 511- 537.

SOFFER O., ADOVASIO J. M., ILLINGWORTH J. S., AMIRKHANOV H. A., PRASLOV N. D. \& STREET M. 2000. Palaeolithic perishables made permanent. Antiquity 74(286): 812-821.

SVOBODA J., LOŽEK V., VLČEK E. 1996. Hunters between East and West. The Paleolithic of Moravia. Plenum Press. New York and London: 157-170.

VAN DER VEEN M. 2003. When is food a luxury? World Archaeology 34(3): 405-427.

VANDIVER B. P., SOFFER O., KLIMA B., SVOBODA J. 1989. The Origin of Ceramic Technology at Dolni Věstonice, Czechoslovakia. Science 246(4933): 1002-1008.

VASIL'EV S. A. 1985. Une statuette d'argile paléolithique de Sibérie du Sud. L'Anthropologie 89(2): 193-196.

VASIL'EV A. S., KUZMIN V. Y., ORLOVA A. L., DEMENTIEV N. Y. 2002. Radiocarbon-based chronology of the Paleolithic in Siberia and its relevance to the peopling of the New World. Radiocarbon 44( 2): 503-530.

VERPOORTE A. 2001. Places of Art, traces of Fire. Archaeological Studies Leiden University 8 (Dolní Věstonice Studies 6). Faculty of Archaeology, University of Leiden \&
Institute of Archaeology, Academy of Sciences of the Czech Republic, Leiden, Brno.

VITELLI D. K. 1993. Franchthi Neolithic Poterrry. Volume 1: Classification and Ceramic Phases 1 and 2. In Excavations in Franchthi Cave, Greece. Fascicle 8. (T. W. Jacobsen ed.). Bloomington \& Indianapolis.

1999. "Looking Up" at Early Ceramcis in Greece. In J. M. Skibo and G. M. Feinman (eds.), Pottery and People: A Dyanmic Interaction. Foundations in Archaeological Inquiry, J. M. Skibo, general editor. University of Utah Press, Salt Lake City: 184-198.

VLASSA N. 1972. Eine frühneolitische Kultur mit bemalter Keramik der Vor-Starčevo-Körös ' Zeit in Cluj-Gura Baciului, Siebenbürgen. Praehistorische Zeitschrift 47: 174197.

WHITTLE A., BARTOSIEWICZ L., BORIĆ D., PETTITT P., RICHARDS M., 2002. In the beginning: new radiocarbon dates for the Early Neolithic in northern Serbia and southeast Hungary. In E. Banffy (ed.), Prehistoric Studies in Memoriam Ida Bognar-Kutzian. Antaeus 25: 15-62.

VOIGT M., M. 2000. Çatal Höyü in Context. Ritual at Early Neolithic Sites in Central and Eastern Turkey. In I. Kuijt (ed.), Life in Neolithic Farming Comunities. Social Organization, Identity and Differentiation. Fundamental Issues in Archaeology. Kluwer Academic and Plenum Publisher, New York: 253-293.

WRIGHT K. 2000. The social origins of cooking and dining in early villages of western Asia, Proceedings of the Prehistoric Society 66: 89-121.

ZHAO C. and WU X. 2000. The Dating of Chinese Early Pottery and Discussion of Some Related Problems. In M. Budja (ed.), 7th Neolithic Studies. Documenta Praehistorica 27: 233-239.

YIOUNI P. 1996. The Early Neolithic Pottery: Functional Analysis. In R. J. Rodden and K. A. Wardle (eds.), Nea Nikomedeia I. Supplementary Volume No. 25. The British School at Atens: 181-191.

ZHUSHCHIKHOVSAYA S. I. 2005. Prehistoric Potterymaking of the Russian Far East. British Archaeological Reports IS 1434. Archaeopress, Oxford. 